Kiryoku, Volume 4 No 12020

e-ISSN:2581-0960p-ISSN: 2599-0497

Tersedia online di http://ejournal.undip.ac.id/index.php/kiryoku

\title{
Analisis Distraktor Butir Soal Bunpou Shokyuu Kouhan Semester 2 Tahun 2018/2019 Prodi Pendidikan Bahasa Jepang Unnes
}

\author{
Resty Anuegrah Putri, Yuyun Rosliyah \\ Universitas Negeri Semarang \\ restyanuegrah25@gmail.com; yuyunrosliyah@mail.unnes.ac.id
}

\begin{abstract}
Abstrak
Distraktor berfungsi untuk mengecoh peserta tes untuk memilih jawaban yang benar. Karena distraktor yang memiliki tingkat kemiripan yang tinggi dengan jawaban yang benar, dapat membuat peserta tes merasa bingung dan kesulitan ketika memilih jawaban.Oleh karena itu, pemilihan distraktor pada butir soal perlu diperhatikan agar berfungsi dengan baik. Tujuan penelitian ini untuk mengetahui distraktor mana saja yang dipilih responden dan keefektifan distraktor butir soal Bunрои Shokyuи Kouhansemester 2 Tahun 2018/2019 dengan pendekatan penelitian deskriptif kualitatif. Sumber data penelitian ini menggunakan butir soal Bunрou Shokyuu Kouhansemester 2 Tahun 2018/2019. Teknik pengumpulan data menggunakan dokumentasi. Teknik analisis data mengadaptasi teori Nurgiyantoro (2010:192-193). Berdasarkan hasil analisis, 36 distraktor pada butir soal ujian tengah semesterBunpou Shokyuu Kouhansemester 2 Tahun 2018/2019 dikatakan efektif karena sesuai dengan kriteria efektivitas distraktor yang digunakan, 21 distraktor dikatakan tidak efektif dan harus direvisi atau dibuang sesuai dengan kriteria efektivitas distraktor yang digunakan.
\end{abstract}

Kata kunci: analisis, butir soal, distraktor

\begin{abstract}
(Title:Analysis Distractor Of The Items Bunpou Shokyuu Kouhan Semester 2 of 2018/2019 Japanese Language Education Program UNNES)Distractors function to outwit test participants to choose the correct answer.Because the distractor has a high degree of similarity with the correct answer, it can make the examinees feel confused and difficult when choosing answers.Therefore, choosing the distractor in the item needs to be considered in order to function properly.In this research, the distractor selected by the respondent and the effectiveness of the BunpouShokyuuKouhan item 2 semester 2018/2019 subject matter with a qualitative descriptive research approach.The data source of this study uses the items in the 2nd semester of BunpouShokyuuKouhan 2018/2019.Data collection techniques using documentation. Data analysis techniques adapted Nurgiyantoro (2010: 192-193). Based on the analysis results, 36 distractors on the BunpouShokyuuKouhan semester 2 semester 2 of 2018/2019 items were said to be effective because they were in accordance with the
\end{abstract}


effectiveness criteria of the distractors used, 21 were said to be ineffective and had to be revised or discarded according to the effectiveness criteria of the distractors used.

Keywords: analysis, item, distractor

\section{PENDAHULUAN}

Evaluasi merupakan bagian yang tidak dapat dipisahkan dari proses pembelajaran. Menurut Sudjino (2011:2) menjelaskan bahwa evaluasi pendidikan adalah kegiatan atau "proses" penentuan nilai pendidikan, sehingga dapat diketahui mutu dan hasil-hasilnya. Di Prodi Pendidikan Bahasa Jepang UNNES, salah satu alat evaluasi yang digunakan adalah tes, yakni tes tertulis, tes lisan, maupun penugasan. Tes tersebut sebagai alat ukur yangmemiliki validitas isi, dirancang sesuai tujuan pembelajaran dan aturan-aturan dalam penyusunannya. Menurut Arikunto (2011:67) sebuah tes dikatakan memiliki validitas isi apabila mengukur tujuan khusus tertentu yang sejajar dengan materi atau isi pelajaran yang diberikan. Bentuk-bentuk tes yang dilaksanakan di Prodi Pendidikan Bahasa Jepang UNNES, yakni ujian harian (UH), ujian tengah semester (UTS), dan ujian akhir semester (UAS). Menurut Sudjana (2010:35) tes sebagai alat penilaian yang diberikan kepada siswa untuk mendapat jawaban dari siswa dalam bentuk lisan, tulisan, dan perbuatan. Pelaksanaan tes tersebut pada setiap mata kuliah beragam, tergantung pada sifat mata kuliah yang ditempuh. Pada mata kuliah yang bersifat kognitif atau mengukur kemampuan berpikir setiap mahasiswa dalam memahami materi yang diberikan menggunakan tes tertulis sebagai alat evaluasi. Tes yang digunakan pada umumnya berbentuk objektif. Arikunto (2013:179) menjelaskan bahwa tes objektif adalah tes yang dalam pemeriksaannya dapat dilakukan secara objektif.

Pada tes objektif terdapat macammacam tes di antaranya tes benar atau salah, tes pilihan ganda, menjodohkan dan tes isian. Pada tes pilihan ganda setiap butir soal memiliki 1 pertanyaan dan opsi jawaban. Dalam opsi jawaban tersebut terdapat jawaban yang benar dan distraktor (pengecoh). Distraktor berfungsi untuk mengecoh peserta tes untuk memilih jawaban yang benar. Pengecoh yang baik adalah yang dapat dihindari oleh anak-anak yang pandai dan terpilih oleh anak-anak yang kurang pandai, jangan sampai terjadi sebaliknya (Wahyuni dan Ibrahim, 2012:141). Karena distraktor yang memiliki tingkat kemiripan yang tinggi dengan jawaban yang benar, dapat membuat peserta tes merasa bingung dan kesulitan ketika memilih jawaban. Pengecoh yang baik adalah yang banyak dipilih secara merata oleh peserta didik, sebaliknya pengecoh yang tidak dipilih secara merata adalah berkualitas kurang baik (Arifin, 2012:279).

Berdasarkan studi pendahuluan, dengan melihat contoh soal tes Bunpou Shokyuu Kouhan Semester 2 Tahun 2018/2019 yang sudah pernah diujikan 
sebelumnya, pada butir soal pilihan gandanya terdapat beberapa distraktor dari butir soal tersebut tidak dipilih oleh peserta tes. Seluruh peserta tes tersebut memilih opsi jawaban yang benar. Dengan demikian, distraktor pada butir soal pilihan ganda tersebut tidak berfungsi dengan baik.Berdasarkan latar belakang diatas, penulis melakukan penelitiandengan judul: "Analisis Distraktor Butir Soal Bunpou Shokyuи Kouhan Semester 2 Tahun 2018/2019 Prodi Pendidikan Bahasa Jepang UNNES". Karena distraktor pada butir soal Bunрou Shokyuu Kouhan Semester 2 Tahun 2018/2019 perlu dilakukan analisis dan belum diketahui keefektifan distraktornya. Dengan demikian, distraktor yang tidak berfungsi dengan baik dapat diperbaiki maupun diganti.

\section{METODE PENELITIAN}

Penelitian ini menggunakan pendekatan penelitian deskriptif kualitatif. Sugiyono (2015:7) metode kualitatif adalah metode yang menghasilkan data yang lebih berkenaan dengan interpretasi terhadap data yan ditemukan di lapangan. Sumber data penelitian ini adalah jawaban ujian tengah semester bagian mondai 3 yang terdiri dari 6 soal dan mondai 4 yang terdiri dari 15 soal pada butir soal Bunpou Shokyuu Kouhan tahun 2018/2019 Prodi Pendidikan Bahasa Jepang UNNES.

Penelitian ini menggunakan teknik dokumentasi, karena data yang diambil berupa dokumen-dokumen tertulis, yakni soal, kunci jawaban, dan lembar jawaban pada ujian tengah semester mata kuliah Bunpou Shokyuu Kouhan tahun 2018/2019 Prodi Pendidikan Bahasa Jepang UNNES. Teknik analisis data menggunakan teori dari Nurgiyantoro (2010:192-193), 1) Semua distraktor (opsi salah) harus ada yang memilih, 2) Jumlah pemilih distraktor (opsi salah) dari peserta kelompok tinggi harus lebih sedikit daripada kelompok rendah, 3) Jika pemilih distraktor (opsi salah) hanya satu, ia harus dari kelompok rendah. Opsi-opsi salah yang tidak efektif karena tidak ada peserta uji yang memilih, sebagai konsekuensinya haruslah dibuang atau direvisi.

\section{PEMBAHASAN}

Berdasarkan rumusan masalah, analisis secara keseluruhan distraktor butir soal ujian tengah semester Bunpou Shokyuu Kouhan semester 2 Tahun 2018/2019 terdapat dua mondai yang digunakan sebagai data. Pertama mondai 3 dan kedua mondai 4.

Distraktor Butir Soal Mondai 3 
Kiryoku, Volume 4 No 12020

e-ISSN:2581-0960p-ISSN: 2599-0497

Tersedia online di http://ejournal.undip.ac.id/index.php/kiryoku

Pembahasan mondai 3 terlihat Tabel

\begin{tabular}{|c|c|c|c|c|c|c|}
\hline Nomor & \multicolumn{3}{|c|}{ Kelompok Atas } & \multicolumn{3}{|c|}{ Kelompok Bawah } \\
\cline { 2 - 7 } $\begin{array}{c}\text { Butir } \\
\text { Soal }\end{array}$ & A & B & C & A & B & C \\
\hline 1 & $15^{* *}$ & - & 1 & $9 * *$ & 2 & 5 \\
\hline 2 & - & $16^{* *}$ & - & 1 & $15^{* *}$ & - \\
\hline 3 & $16^{* *}$ & - & - & $12^{* *}$ & 3 & 1 \\
\hline 4 & - & $16^{* *}$ & - & 2 & $5^{* *}$ & 8 \\
\hline 5 & - & - & $16^{* *}$ & 5 & 9 & $1 * *$ \\
\hline 6 & - & $16^{* *}$ & - & - & $16^{* *}$ & - \\
\hline
\end{tabular}

Tabel 1. Distribusi Jawaban Mondai 3

seperti pada tabel Distribusi Jawaban Mondai 3, di bawah:

Tabel 1. Distribusi Jawaban Mondai 3

Keterangan:

A, B, C : Opsi yang disediakan

Tanda ** : Jawaban benar

Mondai 3 terdiri dari 6 butir soal dengan tiga opsi jawaban, di antaranya terdapat satu jawaban benar dan dua distraktor. Dalam pembahasan ini, dari enam butir soal disajikan tiga contohanalisis, yakni analisis butir soal nomor 1,2, dan 3. Ketiga contoh tersebut adalah sebagai berikut:

\section{Mondai 3. Butir Soal Nomor 1}

1) Pertanyaan : お仕事

$$
\text { は（）ですか。 }
$$

\begin{tabular}{|c|c|c|c|c|c|c|}
\hline & \multicolumn{3}{|c|}{ Kelompok Atas } & \multicolumn{3}{c|}{ Kelompok Bawah } \\
\hline Opsi Jawaban & A & B & C & A & B & C \\
\hline Jumlah yang menjawab & 15 & 0 & 1 & 9 & 2 & 5 \\
\hline Prosentase & $94 \%$ & $0 \%$ & $6 \%$ & $56 \%$ & $13 \%$ & $31 \%$ \\
\hline
\end{tabular}

Tabel 2 Presentase Distraktor (1)

Jika dilihat dari tabel data di atas, kunci jawaban dipilih oleh 15 (94\%) dari responden kelompok atas dan dipilih oleh $9(56 \%)$ dari responden kelompok bawah.

Distraktor pada mondai 3 butir soal nomor 1 adalah B dan C. Opsi B sebagai distraktor tidak dipilih oleh responden kelompok atas $(0 \%)$ dan dipilih oleh $2(13 \%)$ dari responden kelompok bawah.

Opsi C sebagai distraktor dipilih oleh $1(6 \%)$ dari responden kelompok atas dan dipilih oleh 5 (31\%) dari responden kelompok bawah.

\section{Mondai 3. Butir Soal Nomor 2}

1) Pertanyaan : ()

映画が好きですか。

2) Distraktor a. どう

b. どんな c. どれ

3) Kunci Jawaban : b. どんな

4) Presentase Distraktor :

2) Distraktor

:a. なん

b. どんな

c. どれ

3) Kunci Jawaban : a. なん

4) Presentase Distraktor :

\begin{tabular}{|c|c|c|c|c|c|c|}
\hline & \multicolumn{3}{|c|}{ Kelompok Atas } & \multicolumn{3}{c|}{ Kelompok Bawah } \\
\hline Opsi Jawaban & A & B & C & A & B & C \\
\hline Jumlah yang menjawab & 0 & 16 & 0 & 1 & 15 & 0 \\
\hline Prosentase & $0 \%$ & $100 \%$ & $0 \%$ & $6 \%$ & $94 \%$ & $0 \%$ \\
\hline
\end{tabular}

Tabel 2 Presentase Distraktor (2) 
Jika dilihat dari tabel data di atas, kunci jawaban dipilih oleh 16 (100\%) dari responden kelompok atas dan dipilih oleh 15 (94\%) dari responden kelompok bawah.

Distraktor pada mondai 3 butir soal nomor 2 adalah A dan C. Opsi A sebagai distraktor tidak dipilih oleh responden kelompok atas $(0 \%)$ dan dipilih oleh $1(6 \%)$ dari responden kelompok bawah.

Opsi C sebagai distraktor tidak dipilih oleh responden kelompok atas maupun responden kelompok bawah.

\section{Mondai 3. Butir Soal Nomor 3}

1) Pertanyaan : お䒩 とジュースと、（）がい いですか。

2) Distraktor :a. どち ら b. どの c. どこ

3) Kunci Jawaban : a. どち ら

4) Presentase Distraktor :

\begin{tabular}{|c|c|c|c|c|c|c|}
\hline & \multicolumn{3}{|c|}{ Kelompok Atas } & \multicolumn{3}{|c|}{ Kelompok Bawah } \\
\hline Opsi Jawaban & A & B & C & A & B & C \\
\hline Jumlah yang menjawab & 16 & 0 & 0 & 12 & 3 & 1 \\
\hline Prosentase & $100 \%$ & $0 \%$ & $0 \%$ & $75 \%$ & $19 \%$ & $6 \%$ \\
\hline
\end{tabular}

Tabel 2 Presentase Distraktor (3)
Jika dilihat dari tabel data di atas, kunci jawaban dipilih oleh 16 (100\%) dari responden kelompok atas dan dipilih oleh 12 (75\%) dari responden kelompok bawah.

Distraktor pada mondai 3 butir soal nomor 2 adalah B dan C. Opsi B sebagai distraktor tidak dipilih oleh responden kelompok atas dan dipilih oleh 3 (19\%) dari responden kelompok bawah.

Opsi C sebagai distraktor tidak dipilih oleh responden kelompok atas, namun dipilih oleh $1 \quad(6 \%)$ dari responden kelompok bawah.

\section{Distraktor Butir Soal Mondai 4}

Seperti yang sudah disampakan sebelumnya, bahwa pembahasan dilakukan dengan mendananlisis mondai 3 dan 4, maka selanjutnya adalah bahasan mengenai mondai 4 . 


\begin{tabular}{|c|c|c|c|c|c|c|c|c|}
\hline Nomor & \multicolumn{4}{|c|}{ Kelompok Atas } & \multicolumn{4}{|c|}{ Kelompok Bawah } \\
\hline $\begin{array}{l}\text { Butir } \\
\text { Soal }\end{array}$ & A & B & $\mathrm{C}$ & $\mathrm{D}$ & $\mathrm{A}$ & B & $\mathrm{C}$ & $\mathrm{D}$ \\
\hline 1 & - & - & $16^{* * *}$ & - & 4 & 1 & $11^{* * *}$ & - \\
\hline 2 & - & - & - & $16^{* *}$ & - & - & - & $16^{* * *}$ \\
\hline 3 & - & $16^{* * *}$ & - & - & 1 & $15^{* * *}$ & - & - \\
\hline 4 & - & 2 & - & $14^{* * *}$ & - & 3 & - & $13^{* * *}$ \\
\hline 5 & - & - & $16^{* *}$ & - & - & 4 & $11^{* *}$ & 1 \\
\hline 6 & 1 & $15^{* * *}$ & - & - & 10 & $4 * *$ & 1 & 1 \\
\hline 7 & - & - & $16^{* * *}$ & - & - & 2 & $14 * *$ & - \\
\hline 8 & - & - & $16^{* *}$ & - & 1 & - & $15^{* * *}$ & - \\
\hline 9 & 1 & $15^{* * *}$ & - & - & 6 & $9 * *$ & - & 1 \\
\hline 10 & 4 & - & $12^{* * *}$ & - & 5 & 4 & $2 * *$ & 4 \\
\hline 11 & - & - & $16^{* * *}$ & - & 1 & - & $15^{* *}$ & - \\
\hline 12 & - & - & - & $16^{* * *}$ & - & 1 & 1 & $14 * *$ \\
\hline 13 & - & $16^{* * *}$ & - & - & 1 & $10 * *$ & 4 & 1 \\
\hline 14 & $16^{* * *}$ & - & - & - & $11^{* *}$ & 1 & 4 & - \\
\hline 15 & 2 & 1 & $11^{* * *}$ & 2 & 4 & 4 & $3 * *$ & 5 \\
\hline
\end{tabular}

Tabel 2. Distribusi Jawaban Mondai

Keterangan:

A, B, C, D : Opsi yang disediakan

Tanda ** : Jawaban benar

Mondai 4 terdiri dari 15 butir soal dengan empat opsi jawaban, di antaranya terdapat satu jawaban benar dan tiga distraktor. Dalam pembahasan ini, dari lima belas butir soal disajikan tiga contohanalisis, yakni analisis butir soal nomor 1,2, dan 3. Ketiga contoh tersebut adalah sebagai berikut:
1) Pertanyaan : 兄はア
メリカの大学に（）いま
于。

2) Distraktor

:a. 留学

b. 留学する c. 留学して d. 留学の
3) Kunci Jawaban : c. 留学 して

4) Presentase Distraktor :

\begin{tabular}{|c|c|c|c|c|c|c|c|c|}
\hline & \multicolumn{5}{|c|}{ Kelompok Atas } & \multicolumn{5}{c|}{ Kelompok Bawah } \\
\hline Opsi Jawaban & A & B & C & D & A & B & C & D \\
\hline Jumlah yang menjawab & 0 & 0 & 16 & 0 & 4 & 1 & 11 & 0 \\
\hline Prosentase & $0 \%$ & $0 \%$ & $100 \%$ & $0 \%$ & $25 \%$ & $6 \%$ & $69 \%$ & $0 \%$ \\
\hline
\end{tabular}

Tabel 2 Presentase Distraktor (4)

Jika dilihat dari tabel data di atas, kunci jawaban dipilih oleh 16 (100\%) dari responden kelompok atas dan dipilih oleh 11 (69\%) dari responden kelompok bawah.

Distraktor pada mondai 4 butir soal nomor 1 adalah A, B, dan D. Distraktor A dan B tidak dipilih oleh responden kelompok atas. Namun, distraktor A dipilih oleh 4 (25\%) dari kelompok bawah dan distraktor B dipilih oleh $1(6 \%)$ dari responden kelompok bawah.

Distraktor D tidak dipilih oleh responden kelompok atas maupun responden kelompok bawah.

\section{Mondai 4. Butir Soal Nomor 1}


Kiryoku, Volume 4 No 12020

e-ISSN:2581-0960p-ISSN: 2599-0497

Tersedia online di http://ejournal.undip.ac.id/index.php/kiryoku

Mondai 4. Butir Soal Nomor 2

1) Pertanyaan :いつか

$$
\text { 富士山を（）みます。 }
$$

2) Distraktor

:a. 見る

b. 見ない

c. 見た

d. 見て

3) Kunci Jawaban

: d. 見て

4) Presentase Distraktor :

Jika dilihat dari tabel data di atas, kunci jawaban dipilih oleh 16 (100\%) dari responden kelompok atas dan dipilih oleh $16(100 \%)$ dari responden kelompok bawah.

Distraktor pada mondai 4 butir soal nomor 2 adalah A, B, dan C. Ketiga distraktor tersebut tidak dipilih oleh responden kelompok atas maupun responden kelompok bawah.

\section{Mondai 4. Butir Soal Nomor 3}
1) Pertanyaan : 趣味はクラシ ックを（）です。

2) Distraktor :a. 聞く b. 聞 くこと c. 聞いた d. 聞いた
こと

3) Kunci Jawaban： b. 聞くこと
4) Presentase Distraktor :

\begin{tabular}{|c|c|c|c|c|c|c|c|c|}
\hline & \multicolumn{4}{|c|}{ Kelompok Atas } & \multicolumn{5}{c|}{ Kelompok Bawah } \\
\hline Opsi Jawaban & A & B & C & D & A & B & C & D \\
\hline Jumlah yang menjawab & 0 & 16 & 0 & 0 & 1 & 15 & 0 & 0 \\
\hline Prosentase & $0 \%$ & $100 \%$ & $0 \%$ & $0 \%$ & $6 \%$ & $94 \%$ & $0 \%$ & $0 \%$ \\
\hline
\end{tabular}

Tabel 2 Presentase Distraktor (5)

Jika dilihat dari tabel data di atas,

\begin{tabular}{|c|c|c|c|c|c|c|c|c|}
\hline & \multicolumn{5}{|c|}{ Kelompok Atas } & \multicolumn{5}{c|}{ Kelompok Bawah } \\
\hline Opsi Jawaban & A & B & C & D & A & B & C & D \\
\hline Jumlah yang menjawab & 0 & 0 & 0 & 16 & 0 & 0 & 0 & 16 \\
\hline Prosentase & $0 \%$ & $0 \%$ & $0 \%$ & $100 \%$ & $0 \%$ & $0 \%$ & $0 \%$ & $100 \%$ \\
\hline
\end{tabular}

Tabel 2 Presentase Distraktor (6)

kunci jawaban dipilih oleh 16 (100\%) dari responden kelompok atas dan dipilih oleh 15 (94\%) dari responden kelompok bawah.

Distraktor pada mondai 4 butir soal nomor 3 adalah $\mathrm{A}, \mathrm{C}$, dan $\mathrm{D}$. Distraktor A dan $\mathrm{C}$ tidak dipilih oleh responden kelompok atas. Namun, distraktor A dipilih oleh $1(6 \%)$ dari kelompok bawah dan distraktor $\mathrm{C}$ tidak dipilih oleh responden kelompok bawah.

Distraktor D tidak dipilih oleh responden kelompok atas maupun responden kelompok bawah.

Secara keseluruhan, terdapat 21 butir soal dengan 57 distraktor yang harus dipilih oleh responden. Responden dibagi menjadi dua, yakni responden kelompok atas dan responden kelompok bawah. Distraktor yang dipilih oleh responden kelompok 
atas sebanyak 7 distraktor, sedangkan kelompok bawah memilih 36 distraktor, dapat dikatakan distraktor lebih banyak dipilih oleh responden kelompok bawah.

Distraktor dikatakan efektif menurut Nurgiyantoro (2010:192-193), jika 1) dipilih oleh responden, 2) kelompok atas harus memilih lebih sedikit dari kelompok bawah, dan 3) jika hanya dipilih oleh satu responden, ia harus dari kelompok bawah. Sesuai dengan kriteria tersebut, terdapat 36 distraktor dikatakan efektif dan 21 distraktor dikatakan tidak efektif.

\section{SIMPULAN}

Berdasarkan hasil analisis data distraktor butir soal ujian tengah semester Bunpou Shokyuu Kouhan Semester 2 Tahun 2018/2019, terdapat 2 mondai yang digunakan sebagai data, yaitu mondai 3 dan mondai 4. Mondai 3 terdiri dari 6 butir soal dengan tiga opsi jawaban, di antaranya terdapat satu jawaban benar dan dua distraktor. Mondai 4 terdiri dari 15 butir soal dengan empat opsi jawaban, di antaranya terdapat satu jawaban benar dan tiga distraktor.

Secara keseluruhan, pada butir soal tersebut terdapat 57 distraktor yang harus dipilih oleh responden. Responden kelompok atas memilih 7 dari 57 distraktor dan 50 distraktor tidak dipilih. Mereka lebih banyak memilih jawaban benar. Dengan kata lain, pemilih kelompok atas lebih banyak memilih jawaban benar daripada jawaban yang salah (distraktor). Di sisi lain responden kelompok bawah memilih 36 dari 57 distraktor dan 21 distraktor tidak dipilih. Dengan kata lai 63\% lebih distraktor bersifat efektif karena telah dipilih oleh kelompok bawah, sedangkan hampir $37 \%$ responden tidak memilih distraktor tersebut, karena distraktor tersebut dianggap terlalu mudah dianggap sebagai mengecoh, bahkan oleh kelompok bawah sekalipun.

Berdasarkan hasil analisis tersebut, pada mondai 3 terdapat 9 distraktor yang efektif dan 3 distraktor dikatakan tidak efektif karena tidak ada responden yang memilih. Selanjutnya, pada mondai 4 terdapat 27 distraktor yang efektif dan 18 distraktor dikatakan tidak efektif. Distraktor yang tidak efektif dari kedua mondai tersebut lebih baik dibuang atau direvisi, karena distraktor tidak berfungsi dengan baik. Karena distraktor yang dibuang tersebut tidak berfungsi dengan baik, maka sebaiknya diganti dengan distraktor atau pengecoh yang baik, yakni yang efektif karena dipilih oleh responden.

\section{REKOMENDASI}

Dalam setiap menganalisis butir soal, dihasilkan tiga hal, yakni ditemukannya tingkat kesulitan butir soal, daya pembeda butir soal, dan tingkat keefektifan pengecoh atau distraktor. Penelitian ini membahas salah satu dari tiga hal tersebut. Untuk penelitian selanjutnya dapat dilakukan dua hal lagi, yakni meneliti tingkat 
kesulitan butir soal dan meneliti daya pembeda butir soal.

\section{REFERENSI}

Arifin, Zaenal. 2012. Evaluasi Pembelajaran. Bandung: PT. Remaja Rosdakarya

Arikunto, Suharsimi. 2011. DasarDasar Evaluasi Pendidikan. Jakarta: PT. Bumi Aksara.

Arikunto, Suharsimi. 2013. DasarDasar Evaluasi Pendidikan. Jakarta: PT. Bumi Aksara.

Nurgiyantoro, Burhan. 2010. Penilaian Pembelajaran Bahasa Berbasis Kompetensi. Yogyakarta: BPFEYOGYAKARTA

Sudjana, Nana. 2010. Penilaian Hasil Proses Belajar Mengajar. Bandung: PT. Remaja Rosdakarya.

Sudjino, Anas. 2011. Pengantar Evaluasi Pendidikan. Jakarta: Rajawali Pers.

Sugiyono. 2015. Metode Penelitian Kuantitatif kualitatif dan $R \& D$. Bandung: Alfabeta.

Wahyuni, Sri dan Syukur Ibrahim. 2012. Asesmen Pembelajaran Bahasa. Bandung: PT. Refika Aditama 